\title{
The Effect of Heating on Surface Microhardness of Resin-based Materials for Direct Restoration
}

\author{
SIMONA STOLERIU ${ }^{1}$, GIANINA IOVAN ${ }^{1 *}$, IRINA NICA ${ }^{1}$, GALINA PANCU ${ }^{1}$, ANDREI VICTOR SANDU ${ }^{2,3}$, SORIN ANDRIAN ${ }^{1}$ \\ ${ }^{1}$ Grigore T. Popa University of Medicine and Pharmacy lasi, Faculty of Dental Medicine, 16 Universitatii Str., 700115, Iasi, Romania \\ ${ }^{2}$ Gheorghe Asachi Technical University of lasi, Faculty of Material Science and Engineering, 61A D-trie Mangeron Blvd., 700050, \\ lasi, Romania \\ ${ }^{3}$ Romanian Inventors Forum, 3 Sf. Petru Movila, Str. BI. L11, Sc. III, Et. 3, Ap.3, 700089, Iasi, Romania
}

\begin{abstract}
The aim of this study was to evaluate and to compare the surface hardness of three types of resin-based materials used for direct restoration after heating at different temperatures. A giomer (Beautifil II, Shofu Dental), a compomer (Dyract eXtra, Dentsply Sirona) and a hybrid composite resin (Gaenial Posterior, GC Corporation) were selected for this study. Twenty disk-shaped specimens of each material were heated at room temperature $\left(21^{\circ} \mathrm{C}\right)$, at $37^{\circ} \mathrm{C}$, at $50^{\circ} \mathrm{C}$ and at $60^{\circ} \mathrm{C}$. Vickers microhardness test was performed on top and bottom surfaces using digital microhardness tester (Micro-Vickers Hardness System CV-400DMTM, CV Instruments Namicon). The top and bottom surfaces VHN was calculated as a mean value of five determinations. Also, the microhardness ratio was calculated by dividing the top mean VHN value by bottom mean VHN value. Increased mean hardness values were recorded after heating, irrespective of resin-based tested materials. The highest hardness values were recorded after heating all three materials at $60^{\circ} \mathrm{C}$, followed by the hardness recorded at $50^{\circ} \mathrm{C}, 37^{\circ} \mathrm{C}$ and $21^{\circ} \mathrm{C}$. For top surfaces, the lowest hardness value was recorded in DyracteXtra group when samples were warmed at room temperature and the highest hardness value was obtained in Beautifil II group when samples where heated at $60^{\circ} \mathrm{C}$. For the bottom surfaces, Dyract eXtra specimens heated at $21^{\circ} \mathrm{C}$ presented the lowest hardness values and Beautifil II samples heated at $60^{\circ} \mathrm{C}$ presented the highest hardness values. On top and on bottom surfaces Dyract eXtra showed the lowest hardness values, followed by G-aenial Posterior and Beautifil II, irrespective the heating temperature.
\end{abstract}

Keywords: Vickers hardness, compomer, giomer, composite resin

Composite resins have gain popularity during the time and now are the most used materials for direct restoration. Unfortunately, in oral environment, these materials are exposed to different chemical and physical aggressions [1, 2] and are prone to degradation [3]. Dental practitioners have claimed some disadvantages of these materials like polymerization shrinkage, microleakage, postoperative sensitivity, poor marginal adaptation, sensitive technique for placement, difficult handling. The producers made serious effort to improve also mechanical properties of composite resins. It was demonstrated in previous studies that pre-heating before photoactivation decreases material viscosity, which might lead to lower microleakage [4] and better marginal adaptation [5]. Increased surface hardness and enhanced flexural and diametral tensile strength were also reported as a result of overall conversion $[6,7]$. Due to increased temperature by pre-heating the monomer and radical mobility will be enhanced and the degree of conversion will be higher [8-11]. As a result of higher double bond conversion, increased volumetric shrinkage $[12,13]$ and greater shrinkage stress will result during polymerization.

New alternative hybrid direct restorative materials were introduced on the market in the lastdecades. Polyacid modified composites or compomers have dimethacrylate monomer having two carboxylic groups present in their structure and fillers that are similar to the ion-leachable glass present in glassionomer cements. They have some advantages like dentin and enamel adhesion, stable matrix structure, fluoride releasing and reduced microleakage [1417]. Giomers are resin composite with innovative, pre- reacted glassionomer fillers [18]. The inorganic fillers derive from complete or partial reaction of ion-leachable fluoroaluminosilicate with polyalkenoic acids [19]. Some advantages were mentioned for this material: fluoride release and recharge, enhanced mechanical, esthetical and handling properties [20,21]. Lack of knowledge is in the literature regarding the mechanical properties of these hybrid materials when they are preheated. The evaluation of warmed restorative materials mechanical properties is essential to determine the effect of heat on material capability to resist to occlusal forces, fracture and wear. Surface hardness, compressive strength [22], and diametral tensile strength are common investigations to establish the mechanical behavior of restorative materials in oral cavity [23-25].

The aim of this study was to evaluate and to compare the surface hardness of three types of resin-based materials used for direct restoration after heating at different temperatures.

\section{Experimental part \\ Specimen's preparation}

Three resin-based materials: a giomer (Beautifil II, Shofu Dental) (group 1), a compomer (Dyract eXtra, Dentsply Sirona) (group 2) and a hybrid composite resin (Gaenial Posterior, GC Corporation) (group 3) were selected for this study. Details regarding their composition are presented in table 1.

Twenty disk-shaped specimens of each material were obtained using metal molds having $10 \mathrm{~mm}$ in diameter and $2 \mathrm{~mm}$ in thickness. The specimens were randomly

\footnotetext{
*email: gianinaiovan@yahoo.com
} 
Table 1

CHEMICAL COMPOSITION OF RESIN-BASED MATERIALS INCLUDED IN THE STUDY

\begin{tabular}{|l|l|l|l|l|}
\hline $\begin{array}{c}\text { Material for } \\
\text { restoration }\end{array}$ & \multicolumn{1}{|c|}{ Filler } & $\begin{array}{l}\text { Particle size } \\
\text { range }(\mu \mathrm{m})\end{array}$ & \multicolumn{1}{|c|}{ Monomer } & Manufacturer \\
\hline Beautifil II & $\begin{array}{l}\text { Multi-functional glass filler } \\
\text { S-PRG filler (fluoroboroaluminosilicate } \\
\text { glass) }\end{array}$ & $0.01-4.00$ & Bis-GMA, TEGDMA & Shofu Dental \\
\hline Dyract eXtra & Strontium fluoride glass & $0.10-1.40$ & $\begin{array}{l}\text { Bis-GMA,TEGDMA } \\
\text { TMPTMA }\end{array}$ & Dentsply Sirona \\
\hline $\begin{array}{l}\text { Gaenial } \\
\text { Posterior }\end{array}$ & $\begin{array}{l}\text { Pre-polymerized fillers: strontium, } \\
\text { strontium and lanthanoid fluoride, } \\
\text { fluoroaluminosilicate }\end{array}$ & $\begin{array}{l}16.0-17.0 \\
\text { UDMA, } \\
\text { dimethacrylate co- } \\
\text { monomers }\end{array}$ & GC Corporation \\
\hline
\end{tabular}

and equally devided in three subgroups. In subgoup 1 the specimens were preheated at room temperature $\left(21^{\circ} \mathrm{C}\right)$, in subgroup 2 the specimens were preheated at $37^{\circ} \mathrm{C}$, in group 3 the specimens were preheated at $50^{\circ} \mathrm{C}$ and in group 4 the specimens were preheated at $60^{\circ} \mathrm{C}$. In order to obtain a homogeneous warming process and to avoid multiple heating, unidose capsules instead of syringe were used. The capsules of the each material were heated at the specified temperatures for 30 min in a dry-bath incubator (Labline Equipment PVD LTD). A standard time of $30 \mathrm{~s}$ was established to transport the capsules from the incubator and to start specimen preparation. In order to obtain the specimens, the mold was placed on a glass slab, in direct contact to a mylar strip. One layer of each material was condensed into the mold, than the mold was covered with a mylar strip and pressed with a glass slide to remove the excess of the material. The layer of resin-based materials has been polymerized for 40 seconds using a LED light unit (LED B, Guilin Woodpecker Medical Instrument Co., Ltd, China) having the light intensity of 850$1000 \mathrm{~mW} / \mathrm{cm}^{2}$ and the wavelength of $420-480 \mathrm{~nm}$. The specimens were polished with 600,800 and 1200 grit silicon carbide paper under water cooling and than stored in distilled water [19] in a dark recipient at $37^{\circ} \mathrm{C}$ for $24 \mathrm{~h}$.

\section{Microhardness determination}

Vickers microhardness test was performed on top and bottom surfaces using digital microhardness tester (Micro-
Vickers Hardness System CV- 400DMTM, CV Instruments Namicon). A $50 \mathrm{~g}$ load was applied through a Vickers indenter. Five indentations were made for each specimen. A standardize distance of $1 \mathrm{~mm}$ was maintain between two successive indentations. The microhardness was determined by measuring the lengths of the diagonals of the indentation marks and expressed as a Vickers Hardness Number (VHN). The top and bottom surfaces VHN was calculated as a mean value of five determinations. Also, the microhardness ratio was calculated by dividing the bottom VHN value by top VHN value.

\section{Statistical analysis}

Wilcoxon statistical test was used to compare the top and bottom hardness of each material after heating at different temperatures, the hardness values of different materials heated at the same temperature and the hardness ratio of the materials at different temperatures.

\section{Results and discussions}

The mean Vickers microhardness values (VHN) on the top and on the bottom surfaces of three commercial resinbased materials pre-heated at different temperatures are presented in table 2 .

Increased mean hardness values were recorded after heating, irrespective of resin-based tested materials. The highest hardness values were recorded after heating all

Table 2

MEAN VICKERS MICROHARDNESS VALUES (VHN)

\begin{tabular}{|l|l|l|l|l|l|l|l|l|}
\hline \multirow{2}{*}{ Material Temperature } & \multicolumn{2}{|c|}{$21^{\circ} \mathrm{C}$} & \multicolumn{2}{c|}{$37^{\circ} \mathrm{C}$} & \multicolumn{2}{c|}{$50^{\circ} \mathrm{C}$} & \multicolumn{2}{c|}{$60^{\circ} \mathrm{C}$} \\
\cline { 2 - 10 } & Top & Bottom & Top & Bottom & Top & Bottom & Top & Bottom \\
\hline Dyract eXtra & & & & & & & & \\
& 54.24 & 44.93 & 56.05 & 46.56 & 63.58 & 48.23 & 68.83 & 50.37 \\
& \pm 1.34 & \pm 0.99 & \pm 0.48 & \pm 0.60 & \pm 0.77 & \pm 0.70 & \pm 0.45 & \pm 0.67 \\
\hline Beautifil II & 62.74 & 52.42 & 65.83 & 54.65 & 69.42 & 58.63 & 74.68 & 61.34 \\
& \pm 1.11 & \pm 0.94 & \pm 0.47 & \pm 0.44 & \pm 0.80 & \pm 0.40 & \pm 0.44 & \pm 0.31 \\
\hline G-aenial Posterior & 57.81 & 49.54 & 60.13 & 50.13 & 64.37 & 55.37 & 69.05 & 58.47 \\
& \pm 0.42 & \pm 0.34 & \pm 0.24 & \pm 0.29 & \pm 0.34 & \pm 0.18 & \pm 0.14 & \pm 0.54 \\
\hline
\end{tabular}

Table 3

WILCOXON STATISTICAL TEST RESULTS WHEN COMPARED THE TOP SURFACE HARDNESS OF DYRACT EXTRA HEATED AT DIFFERENT TEMPERATURE

\begin{tabular}{|c|c|c|c|c|c|c|}
\hline & T37-T21 & T50-T21 & T60-T21 & T50-T37 & T60-T37 & T60-T50 \\
\hline Z & $-1.214^{\mathrm{b}}$ & $-2.023^{\mathrm{b}}$ & $-2.023^{\mathrm{b}}$ & $-2.023^{\mathrm{b}}$ & $-2.023^{\mathrm{b}}$ & $-2.023^{\mathrm{b}}$ \\
\hline Asymp. Sig. (2-tailed) &. $\mathbf{2 2 5}$ & $\underline{.043}$ & $\underline{.043}$ & $\underline{.043}$ & $\underline{.043}$ & $\underline{.043}$ \\
\hline \multicolumn{8}{|c|}{ a. Wilcoxon Signed Ranks Test } \\
b. Based on negative ranks.
\end{tabular}


Table 4

WILCOXON STATISTICAL TEST RESULTS WHEN COMPARED THE TOP SURFACE HARDNESS OF BEAUTIFIL II AND G-AENIAL POSTERIOR HEATED AT DIFFERENT TEMPERATURE

\begin{tabular}{|c|c|c|c|c|c|c|}
\hline \multicolumn{7}{|c|}{ Test Statistics $^{2}$} \\
\hline & $\mathrm{T} 37-\mathrm{T} 21$ & $\mathrm{~T} 50-\mathrm{T} 21$ & $\mathrm{~T} 60-\mathrm{T} 21$ & $\mathrm{~T} 50-\mathrm{T} 37$ & $\mathrm{~T} 60-\mathrm{T} 37$ & $\mathrm{~T} 60-\mathrm{T} 50$ \\
\hline$z$ & $-2.023^{b}$ & $-2.023^{b}$ & $-2.023^{b}$ & $-2.023^{b}$ & $-2.023^{b}$ & $-2.023^{b}$ \\
\hline Asymp. Sig. (2-tailed) & $\underline{.043}$ & .043 & $\underline{.043}$ & .043 & $\underline{.043}$ & $\underline{.043}$ \\
\hline
\end{tabular}

three materials at $60^{\circ} \mathrm{C}$, followed by the hardness recorded at 50,37 and $21^{\circ} \mathrm{C}$. For top surfaces, the lowest hardness value was recorded in Dyract eXtra group when samples were warmed at room temperature and the highest hardness value was obtained in Beautifil II group when samples where heated at $60^{\circ} \mathrm{C}$. For the bottom surfaces, Dyract eXtra specimens heated at $21^{\circ} \mathrm{C}$ presented the lowest hardness values and Beautifil II samples heated at $60^{\circ} \mathrm{C}$ presented the highest hardness values. On top and on bottom surfaces Dyract eXtra showed the lowest hardness values, followed by G-aenial Posterior and Beautifil II, irrespective the heating temperature.

Significantly statistical results were obtained when compared the top surface hardness of Dyract eXtra, Beautifil II and G-aenial Posterior after heating at different temperature, except Dyract eXtra mean hardness at $21^{\circ} \mathrm{C}$ and $37^{\circ} \mathrm{C}$ (tables 3 and 4 ).

When compared the bottom hardness values, significantly statistical results were obtained for each material when the materials were heated at 21, 37, 50 and $60^{\circ} \mathrm{C}$, except the bottom hardness of Dyract eXtra and Beautifil II heated at 21 and $37^{\circ} \mathrm{C}$ (tables 5, and 6).

The mean microhardness ratio of the tested resin-based materials pre-heated at different temperatures is presented in table 7 . At $21^{\circ} \mathrm{C}$ the lowest hardness ratio was recorded for Dyract eXtra, followed by Beautifil II and Gaenial Posterior. Similar ratio results were obtained for Beautifil II and Dyract eXtra when the materials were heated at $37^{\circ} \mathrm{C}$. At $37^{\circ} \mathrm{C}$, G-aenial Posterior presented higher hardness ratio than Beautifil II and Dyract eXtra. When

Table 5

WILCOXON STATISTICAL TEST RESULTS WHEN COMPARED THE BOTTOM SURFACE HARDNESS OF DYRACT EXTRA AND G-AENIAL POSTEIOR HEATED AT DIFFERENT TEMPERATURE

\begin{tabular}{|l|r|r|r|r|r|r|}
\hline & B37 - B21 & B50 - B21 & B60 - B21 & B50-B37 & B60 - B37 & B60 - B50 \\
\hline Z & $-1.753^{\mathrm{b}}$ & $-2.023^{\mathrm{b}}$ & $-2.023^{\mathrm{b}}$ & $-2.023^{\mathrm{b}}$ & $-2.023^{\mathrm{b}}$ & $-2.023^{\mathrm{b}}$ \\
\hline Asymp. Sig. (2-tailed) & .080 & .043 & .043 & .043 & .043 & .043 \\
\hline
\end{tabular}

Table 6

WILCOXON STATISTICAL TEST RESULTS WHEN COMPARED THE BOTTOM SURFACE HARDNESS OF BEAUTIFIL II HEATED AT DIFFERENT TEMPERATURE

\begin{tabular}{|c|c|c|c|c|c|c|}
\hline \multicolumn{7}{|c|}{ Test Statistics ${ }^{\mathrm{a}}$} \\
\hline & $\mathrm{B} 37-\mathrm{B} 21$ & $\mathrm{~B} 50$ - B21 & $\mathrm{B} 60$ - B21 & $\mathrm{B} 50-\mathrm{B} 37$ & $\mathrm{~B} 60-\mathrm{B} 37$ & $\mathrm{~B} 60-\mathrm{B} 50$ \\
\hline$z$ & $-2.023^{b}$ & $-2.023^{b}$ & $-2.023^{b}$ & $-2.023^{b}$ & $-2.023^{b}$ & $-2.023^{b}$ \\
\hline Asymp. Sig. (2-tailed) & .043 & .043 & .043 & .043 & .043 & $\underline{.043}$ \\
\hline
\end{tabular}

\begin{tabular}{|l|c|c|c|c|}
\hline & $21^{\circ} \mathrm{C}$ & $37^{\circ} \mathrm{C}$ & $50^{\circ} \mathrm{C}$ & $60^{\circ} \mathrm{C}$ \\
\hline Dyract eXtra & 0.80 & 0.82 & 0.75 & 0.72 \\
\hline Beautifil II & 0.83 & 0.82 & 0.84 & 0.81 \\
\hline G-aenial Posterior & 0.85 & 0.83 & 0.85 & 0.84 \\
\hline
\end{tabular}

Table 7

MEAN MICROHARDNESS RATIO OF THE TESTED MATERIALS 
Table 8

WILCOXON STATISTICAL TEST RESULTS WHEN COMPARED THE RATIO HARDNESS OF DYRACT EXTRA HEATED AT DIFFERENT_TEMPERATURE

\begin{tabular}{|c|c|c|c|c|c|c|}
\hline \multicolumn{7}{|c|}{ Test Statistics ${ }^{a}$} \\
\hline & $\mathrm{R} 37-\mathrm{R} 21$ & R50-R21 & R60-R21 & $\mathrm{R} 37-\mathrm{R} 50$ & $\mathrm{R} 37-\mathrm{R} 60$ & $\mathrm{R} 50-\mathrm{R} 60$ \\
\hline $\mathrm{Z}$ & $-1.604^{b}$ & $-2.023^{\circ}$ & $-2.023^{\circ}$ & $-2.032^{c}$ & $-2.032^{\circ}$ & $-2.032^{\circ}$ \\
\hline Asymp. Sig. (2-tailed) & .109 & $\underline{.043}$ & .043 & .042 & .042 & .042 \\
\hline \multicolumn{7}{|c|}{ a. Wilcoxon Signed Ranks Test } \\
\hline \multicolumn{7}{|c|}{ b. Based on positive ranks. } \\
\hline \multicolumn{7}{|c|}{ c. Based on negative ranks. } \\
\hline
\end{tabular}

Table 9

WILCOXON STATISTICAL TEST RESULTS WHEN COMPARED THE RATIO HARDNESS OF BEAUTIFIL II HEATED AT DIFFERENT TEMPERATURE

Test Statistics ${ }^{\mathrm{a}}$

\begin{tabular}{|l|r|r|r|r|r|r|}
\hline & R37 - R21 & R50-R21 & R60-R21 & R37 - R50 & R37 - R60 & R50 - R60 \\
\hline$Z$ & $-.272^{b}$ & $-.406^{\mathrm{C}}$ & $-1.214^{\mathrm{b}}$ & $-.962^{\mathrm{c}}$ & $-1.633^{\mathrm{b}}$ & $-1.841^{\mathrm{b}}$ \\
\hline Asymp. Sig. (2-tailed) & $\mathbf{. 7 8 5}$ & $\mathbf{. 6 8 4}$ & $\mathbf{. 2 2 5}$ & $\mathbf{. 3 3 6}$ & $\mathbf{. 1 0 2}$ & $\mathbf{. 0 6 6}$ \\
\hline
\end{tabular}

a. Wilcoxon Signed Ranks Test

b. Based on negative ranks.

c. Based on positive ranks.

Table 10

WILCOXON STATISTICAL TEST RESULTS WHEN COMPARED THE RATIO HARDNESS OF G-AENIAL POSTERIOR HEATED AT DIFFERENT TEMPERATURE

Test Statistics ${ }^{\mathrm{a}}$

\begin{tabular}{|c|c|c|c|c|c|c|}
\hline & $\mathrm{R} 37-\mathrm{R} 21$ & R50-R21 & R60-R21 & $\mathrm{R} 37-\mathrm{R} 50$ & $\mathrm{R} 37-\mathrm{R} 60$ & $\mathrm{R} 50-\mathrm{R} 60$ \\
\hline $\mathrm{Z}$ & $-2.023^{b}$ & -1.7329 & $-1.857^{6}$ & $-2.032^{c}$ & -1.8419 & $-2.041^{b}$ \\
\hline Asymp. Sig. (2-tailed) & .043 & .083 & .063 & .042 & .066 & .068 \\
\hline \multicolumn{7}{|c|}{ a. Wilcoxon Signed Ranks Test } \\
\hline b. Based on negative ra & & & & & & \\
\hline
\end{tabular}

heated at 50 and $60^{\circ} \mathrm{C}$, G-aenial Posterior presented the highest hardness ratio followed by Beautifil II and Dyract extra.

Statistically significant results were obtained when compared the hardness ratio at different temperature for Dyract eXtra, except the ratio when material was heated at $21^{\circ} \mathrm{C}$ and $37^{\circ} \mathrm{C}$ (table 8). For Beutifil II no significantly statistical results were obtained when compared the hardness ratio of the samples heated at 21,37, 50, and $60^{\circ} \mathrm{C}$ (table 9). For G-aenial posterior statistically significant results were obtained when compared the hardness ratio when the material was heated at $37^{\circ} \mathrm{C}$ to the hardness ratio when the material was heated at $21^{\circ} \mathrm{C}$, when the material was heated at $37^{\circ} \mathrm{C}$ to the hardness ratio when the material was heated at $50^{\circ} \mathrm{C}$ (table 10 ).

Previous studies demonstrated that variables like preheating temperature, composite type and composition, top or bottom surfaces can significantly influence material hardness [10,26]. In our study warming the materials at $21,37,50$, and $60^{\circ} \mathrm{C}$ leaded to higher surface hardness (top and bottom) for all type of resin-based tested materials. Similar results were found in studies that evaluate only the composite resins surface hardness in relation with preheated temperature [26]. It was established that surface hardness evaluation is an indirect method to determine the conversion rate of composite resins. Direct positive relation was established between the hardness and the degree of conversion [27, 28]. Increased degree of conversion (6-18\%) was reported in previous studies when composite resins were pre-heated up to $54^{\circ} \mathrm{C}$ [29]. Similar results were also obtained by Daronch et al. [9], which showed that the degree of conversion was significantly influenced by pre-heated on top and bottom of composite resins. Previous studies showed that a hardness ratio of $80 \%$ can be related to a bottom-to-top conversion of $90 \%$, but the correlation between these two parameters was not very accurate [28]. Also, studies have demonstrated that the rate of conversion is not related to resin-based composite formula [27, 28].

The degree of conversion is in direct relation to the type of composite resin. Dyract extra resin matrix is a mixture of several methacrylate resins like ethoxylated BisphenolA-dimethacrylate, urethane resin, triethylene glycol dimethacrylate (TEGDMA), and trimethylolpropane trimethacrylate (TMPTMA). TCB resin is also included to give the resin mixture a high cohesion, to reduce the hydrofobic characteristics, and to increase the rate of fluoride release. Base resin of Beautifil II is represented by Bis-GMA (7.5 wt\%) and TEGDMA (5 wt\%). Resin matrix of G-aenial Posterior consists of a mixture of urethane dimethacrylate (UDMA) and dimethacrylate co-monomers and is bis-GMA free. Previous studies showed that TEGDMA presented the highest degree of conversion when compared to other resin composite monomers (Gajewski). That could be an explanation for better microhardness 
results obtained for Beautifil II and Dyract eXtra when compared to G-aenial Posterior.

Increasing the temperature of composite resins might lead to a higher molecular mobility and the propagation stage will need longer time without being diffusion controlled. The temperature below the glass transition will improve the mobility of polymer chain, postponing the reaction diffusion-controlled termination [26, 29]. By improving the monomer conversion, the glass transition temperature will be increased due to increased monomer conversion and will induce a greater amount of conversion at higher polymerization temperatures. For dimethacrylate based composite resin a a large increase in polymerization rate will occur at small increase of temperature [8]. It was demonstrated that the higher the degree of conversion, the greater the cross linking and the better the mechanical properties [10,30].

Another factor that can influence the surface hardness is the filler content [31, 32]. Dyract eXtra filler component is represented by strontium fluoride glass and the mean particle size is of $0.8 \mu \mathrm{m}$. Beautifil II is an universal nanohybrid composite that incorporates S-PRG (surface prereacted glass ionomer) technology consisting in stable phase of glass-ionomer (fluroboroaluminosilicate glass). In the filler structure, discrete nano fillers $(10-20 \mathrm{~nm})$ were also added addition in order to obtain a filler load of 83.3 wt\% (68.6 vol\%). Particle size ranges from $0.01 \mu \mathrm{m}$ to 4.0 im, with a mean particle size of $0.8 \mu \mathrm{m}$. Two different kind of pre-polymerized fillers are used in G-aenial Posterior structure. They are produced by polymerizing a resin matrix in which micro-fillers were incorporated, and then milling the polymerized resin into particles averaging 16 to $17 \mu$ in size. The fillers also consist in fumed silica particles and strontium and lanthanoid fluoride dispersed between the pre-polymerized fillers. Total filler load is $77 \%$ by weight and $65 \%$ by volume. In our study, irrespective that Beautifil II and Dyract eXtra materials have the same mean particle size, they showed different hardness due to the fact that they present different filler content. Increased filler content of Beautifil II (83.3 wt\%) and Dyract eXtra might explain the higher hardness values found for this material when compared to G-aenial Posterior ( $77 \mathrm{wt} \%$ ).

In our study increased top and bottom surface hardness was obtain for all three resin-based materials. Top surface hardness was higher than bottom hardness, irrespective of the tested material. One possible explanation is the fact that the activation light is reflected, scattered and absorbed while passing through the material. For composite resins, a $75 \%$ reduction of the irradiance was reported at a depth of $2 \mathrm{~mm}$ when compared to the top surface [33]. Studies reported $50 \%$ to $70 \%$ conversion of monomers at room temperature [34-36]. It is considered a proper polymerization when the bottom/top surface hardness is $80-90 \%$. In our study, all the materials heated at all tested temperatures had the bootom bottom/top ratio ranking from $80 \%$ to $85 \%$, except Dyract eXtra heated at $50^{\circ} \mathrm{C}$ and $60^{\circ} \mathrm{C}$, which showed lower ratio $(75 \%$ and $72 \%$, respectively). Top surface hardness obtained in the present study were similar to that obtained in previous studies [37].

\section{Conclusions}

Warming at $21,37,50$, and $60^{\circ} \mathrm{C}$ significantly increases the surface hardness (top and bottom) for tested compomer, giomer and composite resin. In the conditions of this study, all the materials heated at tested temperatures presented the bootom bottom/top ratio ranking from $80 \%$ to $85 \%$, except Dyract eXtra heated at 50 and $60^{\circ} \mathrm{C}$, which showed lower ratio.

Aknowledgement: This work was supported bya grant of the Romanian Ministery of Research and Innovation, CCCDI - UEFISCDI, project number PN-III-P1-1.2-PCCDI-2017-0239/60PCCDI 2018, within PNCDI III

\section{References}

1.MUNTEANU, B., ANDRIAN, S., IOVAN, G., GHIORGHE, A.C., NICA, I., STOLERIU, S., Mat. Plast., 51, no.3, 2014, p. 279.

2.STOLERIU, S., ANDRIAN, S., PANCU, G., NICA, I., MUNTEANU, A., BALAN, A., IOVAN, G., Mat. Sci. Eng., 133, 2016, 012056, doi:10.1088/ 1757-899X/133/1/012056.

3.NICA, I., IOVAN, G., GHIORGHE, A.C., STOLERIU, S., PANCU, G., ANDRIAN, S., Mat. Plast., 51, no.3, 2014, p. 282.

4.WAGNER, W.C., AKSU, M.N., NEME, A.M., LINGER, J.B., PINK, F.E., WALKER, S., Oper. Dent., 33, 2008, p.

5.FROES-SALGADO, N.R., SILVA, L.M., KAWANO, Y., FRANCCI, C., REIS,

A., LOGUERCIO, A.D., Dent.Mat., 26, 2010, p. 908.

6.DEB, S., DI SILVIO, L., MACKLER, H.E., MILLAR, B.J ., Dent. Mat., 27, 2011, p. 51.

7.BAUSCH, J.R., DE LANGE, C., DAVIDSON, C.L., J. Oral Rehabil., 8, 1981, p. 309.

8.DARONCH, M., RUEGGEBERG, F.A., DE GOES, M.F., GIUDICI, R., J. Dent. Res., 85, 2006, p. 38.

9.DARONCH, M., RUEGGEBERG, F.A., DE GOES, M.F., J. Dent. Res., 84, 2005, p. 663.

10.TRUJ ILLO, M., NEWMAN, S.M., STANSBURY, JW., Dent. Mat., 20, 2004, p. 766.

11.LOVELL, L.G., NEWMAN, S.M., BOWMAN, C.N., J. Dent. Res., 78, 1999, p. 1469.

12.LOHBAUER, U., ZINELIS, S., RAHIOTIS, C., PETSCHELT, A., ELIADES, G., Dent. Mat., 25, 2009, p. 514.

13.WALTER, R., SWIFT, E.J.J., SHEIKH, H., FERRACANE, J.L.,Quintessence Int. 40, 2009, p. 843.

14.MEYER, J.M., CATTANI-LORENTE, M.A., DUPIS, V., Biomaterials, 19, no. 6, 1998, p. 529.

15.EL-KALLA, I.H., GARCIA-GODAY, F., Oper Dent. 24, no. 1,1999, p. 2. 16. ATTAR, N., ÖNEN, A., J. Oral Rehabil., 29, no. 8, 2002, p. 791.

17. SAVIN, C., PETCU, A., GAVRILA, L., MARTU-STEFANACHE, M.A., BALAN, A., International J ournal of Medical Dentistry, 20, no. 3, 2016, p. 171.

18.GORDAN, V.V., MONDRAGON, E., WATSON, R.E., GARVAN, C., MJOR, I.A., J. Am. Dent. Assoc., 138, no. 5, 2007, p. 621.

19.SUNICO, M.C., SHINKAl, K., KATOH, Y., Oper. Dent., 30, no. 3, 2005, p. 282.

20.CAPAN, B.S., AKYUZ, S., Clin. Exp. Health Sci., 6, no. 3, 2016, p. 129. 21.CIRDEI, M.V., MOCUTA, D., OGODESCU, E., PETCU, A., LAZEA, A., TODEA, C., Mat. Plast., 55, no. 2, 2018, p. 230.

22.ANDRIAN, S., PANCU, G., TOPOLICEANU, C., TOFAN, N., STOLERIU, S., IOVAN, G., Rev. Chim. (Bucharest), 68, no. 8, 2017, p. 1874.

23. GHIORGHE, C.A., IOVAN, G., ANDRIAN, S., NICA, I., TOPOLICEANU, C., PANCU, G., Rev. Chim. (Bucharest), 68, no. 8, 2017, p. 1890.

24. TOFAN, N., ANDRIAN, S., NICA, I., STOLERIU, S., TOPOLICEANU, C., CHELARIU, R., BOLAT, M., PANCU, G., Rev. Chim. (Bucharest), 67, no. 6, 2016, p. 1144.

25. GHIORGHE, C.A., IOVAN, G., TOPOLICEANU, C., SANDU, A.V., ANDRIAN, S., Rev. Chim. (Bucharest), 64, no. 12, 2013, p. 1436.

26.TAHEREH, S. JAFARZADEH K., FEREIDOUNI1, F., KHOSHROO1, K., HEIDARI1, S., MASAELI, R., MOHAMMADIAN, M., Front. Biomed. Technol., 2, no.1, 2015, p. 15.

27.DAVID, J.R., GOMES, O.M., GOMES, J.C., LOGUERCIO, A.D., REIS, A., J. Oral Sci., 49, 2007, p. 19. 
28.BOUSCHLICHER, M.R., RUEGGEBERG, F.A., WILSON, B. M., Oper. Dent., 29, 2004, p. 698.

29.TRUJ ILLO, M., STANSBURY, J.W., J. Dent. Res., 82, Special Issue A, 2003, abstract 0819.

30.FERRACANE, J.L., MITCHEM, J.C., CONDON, J.R., TODD, R., J. Dent. Res., 76, 1997, p. 1508.

31.CHUNG, K.H., GREENER, E.H., J. Oral Rehabil., 17, 1990, p. 487. 32.KIM, K. H., ONG, J.L., OKUNO, O., J. Prosthet. Dent., 87, 2002, p. 642.
33.SOLIMAN E.M., ELGAYAR, I.L., KAMAR A.A. Alex. Dent. J., 41, 2016, p. 4.

34.LUCEY, S., LYNCH, C.D., RAY, N.J ., BURKE, F.M., HANNIGAN, A., J. Oral Rehabil., 37, 2010, p. 278.

35.POGGIO, C., LOMBARDINI, M., GAVIATI, S., CHIESA, M., J. Conserv. Dent., 15, 2012, p. 237.

36. SAADE, E.G., BANDECA, M.C., RASTELLI, A.N.S., BAGNATO, V.S., PORTO-NETO, S.T., Laser Phys., 19, 2009, p. 1276.

37. BALAN, A., PERJU, M.C., SAVIN, C., STOLERIU, S., MUNTEAN, A., Mat. Plast., 53, no. 2, 2016, p. 312.

$\overline{\text { Manuscript received: } 3.09 .2018}$ 